\title{
Exploring Technological Pedagogical and Content Knowledge (TPACK) in English Language Classroom Setting: In-Service English Teachers' Perspectives
}

\author{
Galuh Dara Kirana ${ }^{1}$ and Salim Nabhan ${ }^{2}$ \\ ${ }^{1,2}$ Universitas PGRI Adi Buana Surabaya, Indonesia \\ (salimnabhan@unipasby.ac.id)
}

\begin{abstract}
Technological Pedagogical and Content Knowledge (TPACK) is one of today's frameworks that integrates technology in the teaching and learning process. However, little research has been done related to the investigation of in-service teachers' TPACK, particularly its understanding, process, and challenges in English language classroom setting. Therefore, this study aims at exploring TPACK in English language classroom from the perspectives of in-service English teachers. The data were taken from four in-service English teachers in a senior high school in Surabaya, East Java, Indonesia. Qualitative case study was involved as the approach of the study. The researchers utilized the triangulation of data sources including interview, observation, and document to get the data from in-service English teachers as the respondents of the study. The data acquired from the interview were then transcribed verbatim and analyzed using thematic analysis. The current study shows that there are three main themes as findings comprising English teachers' understanding toward TPACK, the process of acquiring TPACK, and the English teachers' challenges toward TPACK. The English teachers had a diverse understanding pertaining TPACK, and they applied various strategies in acquiring TPACK. However, the teachers faced challenges in implementing TPACK. This study might have implications in providing the direction of English teachers' professional development.
\end{abstract}

Keywords: English language classroom; in-service English teachers, TPACK..

Technology nowadays becomes a crucial part of education. Technology is extremely influential in the learning process at schools. The use of technology can help to support learning and teaching process. Since there are many benefits toward the use of technology, teachers are suggested to implement technology in the digital learning. Digital learning as an unplanned and implicit process with unpredictable results using several types of technological devices like smartphones, tablets, computers, and others (Sousa, M. J., \& Rocha, A., 2018). In addition, the term digital learning is used to explain a broad scale of educational chances created by digital technologies (Blundell et al, p. 536). However, the teachers have some difficulties in applying the technology. The lack of knowledge is one of 
the difficulties which teachers have (Thornberg, 2008).

The use of technology which is combined with the particular approach in teaching particular subject is associated with TPACK. As stated by Koehler and Mishra (2006), "TPACK is an integration of technological, pedagogical, and content knowledge". Taopan et al., (2020) also defined technological pedagogical and content knowledge (TPACK) as a structure to describes the knowledge of the teachers. In addition, Ozgur (2020) also stated that Technological Pedagogical Content Knowledge (TPACK) model that includes the combination and interaction of three different disciplines: Technological Knowledge (TK), Pedagogical Knowledge (PK) and Content Knowledge (CK). Tanak (2020) explained that the forms of knowledge are PCK, technological content knowledge (TCK), technological pedagogical knowledge (TPK), and technological pedagogical content knowledge (TPACK). According to Harris and Hoffer (2001), "TPACK is a specialized, highly applied type of knowledge that supports content-based technology integration" (p. 212). The quick transformation of new technologies gives perception for teacher education to be the focus on the three variables related with content, pedagogy, and technology for teacher professional enlargement (Drajati et al., 2018, p. 575). The implementation of technology in the teaching process is more than just the use of the software and the hardware. It also requires the knowledge of the teachers, their pedagogical and technological aspects (Wulandari, 2019, p. 29).

Technology, pedagogy, and content knowledge for English teachers provide a concept that can be applied in the process of learning and teaching. Applying technology in teaching and learning process is one of several difficulties dealing with the teachers' professional development. Assembling teachers to deal with the newest century quality learning needs the capability of teachers in dealing with variation of tools, information, and work that combine with computer-based within the context of the lessons.

Teacher knowledge is every knowledge that teachers have in a certain time which supports their action. It does not mean that every knowledge which they have play a role on their movement. Teachers' comprehension and knowledge are crucial at every level. They enlarge the capability for detecting the chances that they can operate for making students' comprehension forward. When teachers maximize their knowledge to increase student learning, they are appealing in effectual implementation.

The study written by Jen et al. (2016) recommends how teachers go through about their surroundings and the encouragement available for their teaching with technology should be contemplated and must be designated if the enlargement of teachers' TPACK-P is to be chased. In addition, there was a study written by Chai et al. (2011) examining the design rationality of a TPACK that was contextualized for the pedagogical methods employed in a 12-week ICT course created with reference to the TPACK concept for Singaporean primary school pre-service teachers.

Although several researchers (Chai et al., 2011; Drajati et al., 2018; Wulandari, 2019) have identified the implementation of TPACK in its' development as well as developing learning materials, the study pertaining TPACK focusing on the understanding, process, and challenges is still under examined. Therefore, this study aims at exploring TPACK in English language classroom setting from the perspectives of in-service English teachers. The study will focus on the EFL teachers' understanding toward TPACK, the process of acquiring it, and their challenges in its implementation.

\section{Method \\ Approach of the Study}

The qualitative case study was selected as the approach of the study since this study aims to explore TPACK of particular in-service 
English teachers in English classroom setting.

\section{Data and Source of Data}

The data used in this study were the qualitative data. Interview transcription was used as the main data, and notes of observation as well as document of teachers' lesson plans were used as supporting data to give more detail clarification and information regarding the implementation of TPACK. The data were taken from four in-service English teachers in a senior high school in Surabaya, East Java, Indonesia. The participants consisted of senior teachers who are basically older in their age and have experiences in teaching English for more than ten years and young teachers who have been engaging with technologies in their day-to-day activities. They were selected purposefully in terms of the researchers' familiarity with the teachers and their specific profile in implementing TPACK in their English classroom.

\section{Data Collection Techniques}

In general, the data collection techniques used in the study were face-toface unstructured interview, observation, and document. In collecting the data, researchers followed several steps including preparing the interview schedule, developing the interview questions, conducting the interview to the English teachers and recording it, and finally transcribing the interview verbatim. To support the main data, researchers also observed the way teachers taught their students in their classroom online using video conference platform and made several relevant notes of observations. Study the documents were also used to give additional data of the study. In this case, researchers studied the teachers' lesson plan pertaining the implementation of TPACK.

\section{Data Analysis}

The data of this research were analyzed using thematic analysis. Delahunt and Maguire (2017) stated that "Thematic analysis is the process of identifying patterns or themes within qualitative data" (p. 3352). The aim of a thematic analysis is to distinguish themes, such as patterns in the data that were crucial or engaging, and used these themes to approach the research or mentioned something about a topic. This is more than simply recapitulating the data; a good thematic analysis explicated and made sense of it.

In thematic analysis, researchers followed several steps including being familiar with the data, generating initial codes, searching for themes, reviewing themes, defining themes, and finally writing up.

\section{Results and Discussion}

There were three main themes as research findings generated in the study. They were English teachers' understanding toward TPACK, the process of acquiring TPACK, and the English teachers' challenges toward TPACK

\section{Theme 1. English teachers' understanding toward TPACK.}

The association of TPACK on the use of technology

The definition of TPACK was a framework which integrated three aspects. Those three aspects were technology, pedagogy, and content knowledge. However, not every teacher that the researcher interviewed had a comprehensive understanding toward TPACK. It could be seen on the answer of the teacher: (Yes, I know. Based on what I know, TPACK is learning system using technology approach. In a simple way, teacher know how to use internet, supporting applications for the learning process) (T. 1).

Based on that answer, it explained that teacher tended to assume TPACK was all about the technology. Whereas TPACK was not only about technology. There were two aspects more other than technology which were pedagogy and content knowledge.

In fact, there was also a teacher who did not understand fully about TPACK. It could be seen on the following answer: (I do not know 
that much about that, just a little. Wait, let me search it on Google for a while.) (T. 2).

However, one of the teachers had a good understanding towards TPACK: (TPACK, yes? If I am not mistaken, it is a framework that combines technology, pedagogy, and content. I have heard when I studied in a college) (T. 4).

In short, the understanding toward TPACK of the teachers were various. There were teachers who did not know about TPACK and the other teachers were able to explain the definition of TPACK based on their own understandings.

Teachers' awareness of the importance of TPACK toward teachers' self-image and identity

As teachers who taught many students in the school, they wanted to be a good example for the students. This was reflected from the teacher's response such as: (For me it is crucial because as a teacher I do not want to look incapable by my students. I want to be a great teacher so that my students can understand what I taught towards them) (T. 1).

Another response believed that students automatically evaluated the quality of their teachers:

Of course, it is crucial. Moreover, for an English teacher, right? There are lots of material, and the material itself is very broad. It is just how good I am to make my teaching style various. Moreover, the students must evaluate our quality as a teacher, and I want to be a qualified teacher. (T. 4).

In this case, turned out that teachers wanted to had good image and identity so that they could be seen as good quality teacher in front of their students.

Implementing TPACK as part of teachers' selfsustainable development

The use of TPACK also gave an impact for teachers' sustainable self-development as explained by the teacher: (It is very crucial because if we're not update and do not want to learn, we will be stuck there) (T. 3). He explained that the teacher knowledge and skill would not be improved if they did not want to learn continuously toward their technological pedagogical content knowledge. That was why teacher still learned continuously so that their TPACK would be improved to be better.

TPACK and teachers' goal on students' materials understanding and interest

To create good learning outcome for the students, the teacher should explain the materials clearly and had various ways of teaching style. As the teacher aware of the importance of TPACK, they realized that the quality of their TPACK would affect their pedagogical. One of the respondents stated: (It will affect if my TPACK is bad, then the way I teach my students will be monotone. The students will get bored and do not understand the subject that I explained) (T. 2).

This explained that if the teacher used the same method without involving TPACK to teach the students, the students would get bored. Then the boredom of the student would make them not to understand the material clearly.

To make the students active and interest on the learning process was quite difficult for the teachers. If the teachers had good TPACK, it would make them had various ways of teaching. As stated by one of the teachers, TPACK affected on the way they taught the students:

It really affects the way I teach because if our TPACK is great we will have lots of variety to teach. We can use different technology or learning media. So that the students will curious if they learn using learning media that they have never used. It makes them excited because they learn by using something new. (T. 1).

According to the explanation of one of the teachers, it was clear that the students tended to be interested in the learning process if they learned or used something new. It brought out their excitement that it increased their interest. 
Theme 2. The process of acquiring TPACK for English teachers

\section{English teachers' forum programs}

There was teachers' forum program for every subject for the teachers. It also applied for English teachers. One of the teachers (T1) said that the forum had some benefits and positive activities: All English teachers in Surabaya have association. It is called MGMP. MGMP stands for "Musyawarah Guru Mata Pelajaran". MGMP conducts seminars, workshops, or webinars every day. Sharing about new methods, how to use applications. So, as a teacher I have to be active in order to keep updated. (T. 1).

As stated by the teacher, the forum often conducted positive activities such as webinars, seminars, and workshops. It helped the teacher to acquire technological pedagogical content knowledge to improve the teachers' skills.

\section{Teachers' professional development activities}

Usually, the government conducted a training activity for teachers annually. It was attended by the teachers to improve their skills. It was one of the ways for the teacher to acquire technological pedagogical content knowledge which stated by one of the respondents:

Usually there is training activity for the teachers held by the government. We can learn something new from that training. So that, we can improve our quality as a teacher. Especially for the old teacher just like me. I need to have the eager to learn and keep updated with the technological developments to combine with my teaching method. (T. 1)

It could be seen for teachers, especially for older teacher, they tended to acquire the TPACK through the training activity held by the government.

\section{Colleague support}

As a fellow teacher, whenever they found difficulties, they tended to ask help from other teachers. One of the teachers explained her method to acquire TPACK: (I often share something with other teachers. So that I can keep updated and can learn continuously.) (T.
2). It explained that colleague support could be crucial for fellow teachers.

\section{Independent learning}

In acquiring technological pedagogical content knowledge could be through independent learning. It was reflected from the response of the teacher:

I am more into self-learning. So, I look up on the internet which new applications or social media that I can use for the learning media. I usually do the homework different for each class, but with the same value. It also applies the same for making material or subject. Even though the learning topic is the same, I usually make the example question different so that it will not be the same for each class. Other than look up on book for the material, I usually search it on the internet too. But still I must reread it. So, just in case there is something wrong, I can correct the resource materials. (T. 4).

It described that the teacher maximized the use of the internet. He used the internet to learn something new about technology, pedagogy, and content knowledge.

\section{Theme 3. The English teachers' challenges in implementing TPACK}

\section{Technical problems}

Related to the challenges of English teachers' in TPACK, one of the senior teachers showed that his challenges were not able to utilize technology in teaching activities: (Just like what I have said because I am old enough, sometimes there's something that I just don't understand about the technology for the learning process. If I find any difficulties in using it, I ask fellow teacher or my child.) (T. 3).

Based on the observation, it was also noted that the senior English teachers got difficulties in using applications.

However, young teachers had no problems with technical terms: (So far, I do 
not find any difficulties. It perhaps because I am still young, I can say that keeping up with the technology is easy for me. I easily combine the technology with the way I teach) (T. 1). Another teacher also stated that he did not find any difficulties: (It is not too difficult for me. It is just how well I combine those 3 aspects and how I apply it on the way I teach my students.) (T. 4).

Adapting with variety of new technology related to the material taught

Another response of the young teacher related to their difficulties in technological pedagogical content knowledge was to adapt with the new technology (I cannot say that it is difficult, but I have to adapt with that many number of applications nor learning media which have to be used. Especially in this pandemic, all the learning process requires technology.) (T. 2).

In addition, it also could be seen from the result of the observation in the field that the teacher used different media while he was teaching the students. Moreover, study document of the teacher's lesson plan also indicated that the teacher used common tools for certain activities such YouTube video in presenting the material and WhatsApp for sharing information.

\section{Discussion}

The in-service English teachers' comprehension toward TPACK were dissimilar. Every teacher had their own understanding toward technological pedagogical content knowledge. Some knew it comprehensively and other teachers only understood the surface level of TPACK. In other words, the teachers who explained the conception of TPACK based on their own perspectives, they perceived TPACK as the use of technology. Whereas TPACK consists of not only just the use of technology but also the involvement of pedagogy and the content. This result inversely proportional to the study by Aniq and Drajati (2019) showing that the perceptions of EFL teachers had more knowledge about $\mathrm{PK}, \mathrm{CK}$, and PCK than for TK, TCK, and TPK. As stated by Mishra and Koehler (2006), the definition of PK (pedagogical knowledge) concerns with pedagogical knowledge as a knowledge domain that covers the comprehensive knowledge about the teaching process, practices, and methods. In addition, they also showed the comprehension of technological content knowledge as the knowledge domain about the mutual relationship between technology and content. It shows that teachers tend to lack understanding on the content and pedagogical aspects.

Technological pedagogical content knowledge itself was crucial to the teachers as it was related to their image and identity as a teacher whether they had good or bad quality. They wanted to have good image in the eyes of their students because they believed that they were silently being assessed by their students. Since they wanted to be teachers who had good qualification, it generated their eager to learn continuously, so that they can improve their quality to get better. As qualified teachers, they tended to have various ways of teaching. It affected on the students' learning because it could emerge the students' interest which led to the better understanding of the students toward the material. If the students had better understanding toward the material that the teachers taught, it made their learning outcome better.

Each teacher had different way to acquire their technological pedagogical content knowledge. One teacher explained that he joined teachers' forum program called MGMP which stands for Musyawarah Guru Mata Pelajaran. That forum provided free webinars, seminars, and workshop for English teacher which contained materials about new technology for learning process in the classroom and others. The schedule of the webinars, seminars, or workshop was shared in the WhatsApp group. That forum could be one of the ways to improve the skills of the teachers. It depended on how active the teachers were. 
The government provided training activity for all the teacher includes English teacher to attend seminar and workshop. It was usually conducted on particular city to gather the teachers.

Other than webinar, seminar, or workshop, colleague support played an important role in acquiring TPACK because they could share or helped as fellow teacher. Whenever certain teachers got a new information about learning process, they would share it to another teacher so that they could learn together. The use of internet can be maximized for teachers for independent learning. It also could be one of the ways for teachers who wanted to acquire TPACK. Since internet provided broad knowledge for the materials and also the technology, teachers can look up to the internet to acquire their TPACK. They can search every information that they need to know toward TPACK. There were a lot of journals, thesis, and even e-book which provided reliable sources needed by the teachers. Teachers learnt about new technology and looked up to new materials which might be useful for further learning process.

Teachers found difficulties in technological pedagogical content knowledge. One of the difficulties faced by the teachers was about the technical problems. The teachers were not able to the use of some media in teaching activities, especially for the older teachers because they were not used to it. It was in line with the study by Taopan, Drajati and Sumardi (2020) which explained that IT literate become one of the challenges that was faced by the English teachers. They realized that they lacked that capability and sometimes still needed help when it came to technical issues. This was where colleague support played an important role because they could help each other whenever one found difficulties. Another challenge in TPACK was teachers need to adapt with variety of new technology which increased as the day goes by. They needed to learn to that new technology and get used to it for the learning process. However, not every teacher faced difficulties in TPACK because some teachers, especially for the younger one stated that they did not find any difficulties. The result of this study is in line with the study by Chuang and Baran (2011) saying that the intrigue of TPACK framework and the TPACK survey utilization for evaluating and establishing teacher knowledge in many international teacher circumstances is a comprehensible sign of the effect of TPACK as an appearing research and evolution of tool for teachers in education.

\section{Conclusion}

The study has explored the in-service teachers' perceptions toward TPACK in English language classroom setting. The result indicated that the English teachers' comprehension toward technological pedagogical content knowledge was varied. Although most teachers perceived TPACK as the use of technology, they were aware that implementing TPACK represented their self-capability, professional development, and brought learners' understanding and interest. Even though they had various strategies in acquiring TPACK including teachers' forum and training involvement, colleague support, and self-learning, they faced several challenges in implementing TPACK particularly in term of technology adaptation in their classroom. Taken all together, this study directed the importance of understanding and implementing TPACK in English language classrooms.

\section{References}

Baran, E., and Chuang, H. (2011). TPACK: An emerging research and development tools for teacher educators. The Turkish Online Journal of Educational Technology, 10(4), 370-377.

Blundell, C., Lee, K., \& Nykvist, S. (2016). Digital learning in schools: conceptualizing the challenges and influences on teacher practice. Journal of Information 
Technology Education: Research, 15, 535560.

Chai, C. S., Koh, J. H. L., Tsai, C., \& Tan, L. L. W. (2011). Modeling primary school pre-service teachers' Technological Pedagogical Content Knowledge (TPACK) for meaningful learning with information and communication technology (ICT). Computers \& Education, 57(1), 1184-1193. https:// doi.org/10.1016/j.compedu.2011.01.007.

Drajati, N.A., Tan, L., Haryati, S., Rochsantiningsih, D., \& Zainnuri, H.(2018). Investigating English language teachers in developing TPACK and multimodal literacy. Indonesian Journal of Applied Linguistic, 7(3), 575-582. Retrieved from https://www.researchgate.net/ publication/323047453_Investigating _ English_language_teachers_in_ developing_TPACK_and_multimodal_ literacy

Harris, J. B., \& Hofer, M. J. (2001). Technological Pedagogical Content Knowledge (TPACK) in action: A descriptive study of secondary teachers' curriculum-based, technology-related instructional planning. Journal of Research on Technology in Education, 43(3), 211-229. Retrieved from https:// files.eric.ed.gov/fulltext/EJ918905.pdf

Jen, T., Yeh, Y., Hsu, Y., Wu, H., \& Chen, K. (2016). Science teachers' TPACKPractical: Standard-setting using an evidence-based approach. Computers \& Education, 95, 45-62. https://doi. org/10.1016/j.compedu.2015.12.009.

Koehler, M. J., \& Mishra, P. (2006). Technological pedagogical content knowledge: A framework for teacher knowledge. Teachers College Record, 108(6), 1017-1054.

Maguire, M., \& Delahunt, B. (2017). Doing a Thematic Analysis: A Practical, Step-by-
Step Guide for Learning and Teaching Scholars. All Ireland Journal of Teaching and Learning in Higher Education, 8(3), 3351-33514. Retrieved from http://ojs. aishe.org/index.php/aishe-j/article/ view/335

Ozgür, H. (2020). Relationships between teachers' technostress, technological pedagogical content knowledge (TPACK), school support and demographic variables: A structural equation modeling. Computers in Human Behavior, 106468. Retrieved from https://scihub.wikicn.top/https:// doi.org/10.1016/j.chb.2020.106468\#

Sousa, M. J., \& Rocha, A. (2018). Digital learing: Developing skills for digital transformation of organizations. Future Generation Computer Systems (91), 327334. doi: 10.1016/j.future.2018.08.084

Tanak, A. (2020). Designing tpack-based course for preparing student teachers to teach science with technological pedagogical content knowledge. Kasetsart Journal of Social Sciences, 41(1), 53-59. Retrieved from https:// doi.org/10.1016/j.kjss.2018.07.012

Taopan, L. L., Drajati, N. A., \& Sumardi. (2020). TPACK Framework: Challenges and opporunities in EFL classrooms. Research and Innovation in Language Learning, 3(1), 1-22. Retrieved from http://jurnal.unswagati.ac.id/index.php/ RILL/article/download/2763/pdf

Thornberg, R. (2008). The lack of professional knowledge in values education. Teaching and Teacher Education, 24, 1791-1798. doi: 10.1016/j.tate.2008.04.004

Wulandari, E. (2019). Teacher's Technological Pedagogical Content Knowledge in developing learning materials. Lingua Pedagogia, Journal of English Teaching Studies, 1(1), 29-45. Retrieved from https://doi.org/10.21831/lingped. v1i1.23983 